\title{
甲殼類の脱皮に関与するホルモン
}

\section{納 谷 洋 子*}

\section{Crustacean Hormones on Preparations for Molting.}

YOKO NAYA

\begin{abstract}
The presence of a molt-inhibiting hormone (MIH) in crustaceans versus the molting hormone (ecdysteroids) has been biologically demonstrated, however, only a little of the chemical nature of MIH is known so far. Oưr attempt to isolate MIH produced in the X-organ of the eyestalks (ES) resulted in the characterization of xanthurenic acid as an ecdysone biosynthesis inhibitor (EBI). In addition, it was found that 3-hydroxy-L-kynurenine $(3-\mathrm{OH}-\mathrm{K})$ present in the $\mathrm{X}$-organ of ES was also biotransformed into xanthurenic acid. The inhibitory action was shown in the cultured $\mathrm{Y}$-organ-complex homogenate as well as in the crayfish by injection of 3-OH-K that revealed the delay of ecdysis. The preliminary study of $\mathrm{ED}_{50}$ of the active compounds appeared to account for most of but not the full potency of ES extract. Therefore, a molt-inhibiting phenomena is probably the result of the action by the multiple factors including EBI. After the mode of inhibitory action of the recently isolated sinusgland neuropeptide is shown, the involvement of a hormone in the negative control of molting will be clarified.
\end{abstract}

\section{1. はじめに}

甲殼類 (エビ，カニなど)が成長するためには，硬い外 款を脱皮 (ecdysis) しなければならない(図 1. 脱皮周期の 概念図)。体重が増加するという観点からは, 生活環は 周期的に休止 ( C 期) している。脱皮という定義には1), 脱皮 (E 期) と, その前 ( $\mathrm{D}$ 期) 後 $(\mathrm{A}, \mathrm{B}$ 期) に発生する新 陳代謝の変化も含まれる。古い外殼は退化して, キチン

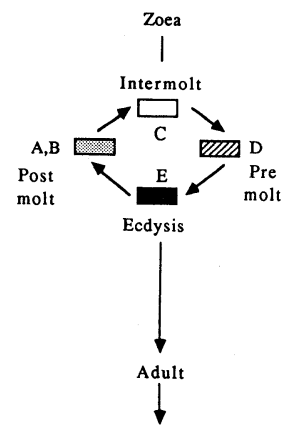

Fig. 1 Stages of the molt cycle designated as A-E.

* (財) サントリー生物有機科学研究所

* Suntory Institute for Bioorganic Research
質は $N$-アセチルグルコサミンにまで分解され, 数層か らなる新しい外款が合成され, 殸のカルシウムは体内に 吸収されて生物によっては胃石を形成し, 鉗脚 (鋏)など の筋肉は水分を失って一旦収縮し脱皮を円滑に行わしめ るが, 脱皮のあとで復元する。このような脱皮のカスケー ド反応や, 脱皮周期を支配する生物時計が内分泌機能に よって制御されていることはいうまでもないが, 分子構 造のレベルで理解されているのは極めて限られた範囲に すぎない。

現象的にみると, ガザミ(Portunus trituberculalus)の例 では, 孵化後ゾエア (zoea), メガローパ(megaropa) と呼 ばれるプランクトン生活史を経て, 幼生のカニに変態し, 約 13 回の脱皮を繰り返す。13 回の脱皮を行う頃には甲 巾は $13 \sim 16 \mathrm{~cm}$ に達し性的にも成熟して，オスは数日間 の追尾行動 (メスの性的分泌物支配と推定されている)に より, メスの脱皮を待って交尾する。メスは精子を貯精 囊に貯えたまま越冬し, 初夏の頃に数回にわたで産卵す る。交尾期のメスはオスによって保護されるが, 脱皮直 後のカニは脱皮しないカニによる共食いの対象になり， 水槽で飼育する時には脱皮ごとに生存数は約半数に減少 する。幼生期の脱皮周期は 2，3 日から数日間であるが， 成長するに従って長くなり遂には数カ月を超える。脱皮 の終焉は明確でなく甲巾が $30 \mathrm{~cm}$ ほどの大型ガザミも知 られている。硬い外殼は外敵に対する優れた防禦機構で 
あるが，成長するために必要な脱皮は生命の危険を伴っ た大事業である。

\section{2. 脱皮の “合図” 物質}

脱皮を支配する因子は自然条件 (海温，光量などの季 節変化), 外傷などに起因した歩脚の自己切断による整 理的刺戟，最も直接的には神経分泌系㧍よび内分泌系の 変化である。脱皮現象は複雑で，いくつかのホルモン支 配が絡み合っていると推定されている。

1905 1939 年の生物学的な実験 ${ }^{2,3)}$ によると, 眼柄の 切除によって脱皮の周期 $(\mathrm{A} \sim \mathrm{E}$ 期) は短縮されて未成熟 のまま早期脱皮 (precocious molt) が進行し, 眼柄の再移 植によって短縮効果は失われ，脱皮周期は復元される。 この結果に基づいて眼柄にある脱皮抑制機能器官を X と 呼び，発想的な関連によって脱皮に関わる器官を $\mathrm{Y}$ とし た。後に，脱皮抑制ホルモン (MIH：molt inhibiting hormone) はX 器官サイナス腺複合体 (X-organ-sinus gland complex) で生産され, 胸凯内にあるY器官に運ば れて，そこで生産されるエクジソン (ecdysone：脱皮ホ ルモン前駆体) の分泌を制御するという概念が定着し だ)。昆虫の場合と同様に, エクジソンは標的器官 (主 として肝膵臓)に運ばれて20-ヒドロキシエクジソン (20-hydroxyecdysone：活性脱皮ホルモン)に変換されて 脱皮を誘発する ${ }^{4)}$ 。1960 年代には甲殼類のY 器官は昆虫 の前胸腺と相同であると述べられている。エクジステロ イド (ecdysteroids，エクジソン類)の初発反応は RNA ポ リメラーゼ I の活性化であるとされているが55,6)，複数 の連鎖反応が介在することはいうまでもない。特にドー パデカルボキシラーゼの生合成の鍵を握ることが証明さ れているク。

MIH の化学的研究の基礎は, in vitro の生物検定法の 確立によって急速に進展した。即ち, 摘出した $\mathrm{Y}$ 器官の 器官培養によって産生する脱皮ホルモン(エクジステロ イド)の生産 ${ }^{8}$ 量を対照区として, 眼柄の抽出物を添加 培養した場合に減少するホルモンの生産量を測定して抑 制効果を判定するものである。

2.1. $\mathrm{Y}$ 器官と脱皮ホルモン4,9) $\mathrm{Y}$ 器官は甲款類の種 類によって存在場所が異なり，脱皮周期の時期によって も消長があるので間違った情報が多いが, エクジソンを 産生する内分泌器官であることは定説になっている。一 般にカ二のY 器官は, 胸凯内の眼孔下縁付近にある大顎 外部筋 ( $\mathrm{Y}$ 字筋) に接して存在する微小器官である (図 2 および文献 4,6 の図または写真参照)。

脱皮周期の休止期 ( $\mathrm{C}$ 期)に $\mathrm{Y}$ 器官を切除すると, 一連 の脱皮現象 (D, E, A, B 期の反応) は阻まれ, 胃石 (ザ

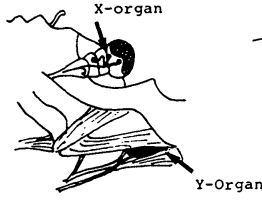

crabs

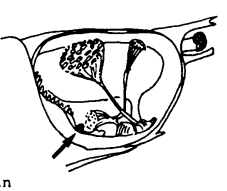

crayfish
Fig. 2 Locations of $\mathrm{X}$-organ and $\mathrm{Y}$-organ are schematically illustrated.

リガニなど)も形成されないが，エクジステロイドを数 回注射すると，切除による障害は失われて胃石が形成さ れ，脱皮現象は完遂される。ちなみに，甲殼類のエクジ ステロイドとしては, エクジソン (1)，20-ヒドロキシ エクジソン (2), イノコステロン(3), マキステロンA (4)，ポナステロン(5)，2-デオキシ-20-ヒドロキシエ クジソンなどがある(図 3)。

一旦脱皮 $\mathrm{D}$ 期の変化が始まると反応はカスケード的に 進むので, $\mathrm{D}$ 期以降で $\mathrm{Y}$ 器官を切除するとその効果は次 の休止期 $(\mathrm{C}$ 期) に持ち越される。生物の体液中のホルモ ン量(エクジステロイド)は脱皮周期の時期によって変動 し, $\mathrm{D}_{2}$ 期では $\mathrm{C}$ 期の 100 200 倍に上昇するが, 脱皮 $(\mathrm{E}$ 期) 直前の $\mathrm{D}_{3-4}$ 期には下降する。 $\mathrm{A}$ 期には極少量になり, $\mathrm{B}$ 期に上昇して $\mathrm{C}$ 期に恒常状態になる。 $\mathrm{C}$ 期は最も長い 期間であって, 脱皮周期の約 $3 / 4$ を占めている。この木 ルモン変動のパターンは, 培養したY $\mathrm{Y}$ 器官から分泌され るエクジステロイドについても摘出母体の周期を保持し ている。従って, 培養によってエクジソンを分泌するの は，C期の後半に摘出した Y 器官だけである。

甲殼類は大多数の昆虫と同様にコレステロールを生合 成しないので，経口的に得たコレステロールを細胞膜の

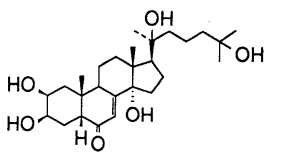

(1)<smiles>CC(C)(O)CC(C)(C)O</smiles>
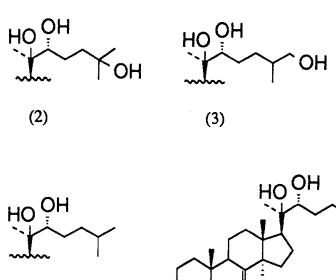

(5)

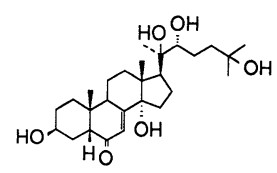

(6)
Fig. 3 Crustacean ecdysteroids : (1) ecdysone, (2) 20-hydroxyecdysone, (3) inokosterone = callinecdysone A, (4) makisterone $\mathrm{A}=$ callinecdysone B ( 5 ) ponasterone, (6) 2-deoxy-20-hydroxyecdysone. 
構成要素として利用するとともに，ホルモン前駆体とし て利用しており， ${ }^{3} \mathrm{H}$ ラベル化したコレステロールと $\mathrm{Y}$ 器官を培養して，エクジステロイドに変換されることが 示されている。エクジソンの 4 環性骨格に対して特異的 な抗体が作製されたことによってエクジステロイドの検 出が容易になり (RIA)，抗体法によって分離された体液 中のエクジステロイドは，20-ヒドロキシエクジソンを 主成分とすることが明らかにされた(質量分析法)。さら に, Y 器官内で生産されるエクジソンは貯蔵されること なく体液中に分泌され，標的組織で 20 位の水酸化を受 けることが確かめられた。

\section{2. $\mathrm{X}$ 器官と脱皮抑制因子 ${ }^{4,9)}$ 昆虫のアラ夕体か} ら分泌される幼若ホルモン $(\mathrm{JH})$ は早熟防止のホルモン であり, 甲殼類の体液中および大顎器官 (mandibular organ) ${ }^{10)}$ にも分布 (JH- III) (図 $4: 7$ ) しているが，その生 体内での生理的作用は明らかにされていない。一方，現 象的に脱皮を抑制する眼柄中の因子は脱皮抑制ホルモン (MIH) と名付けられているが，将来その作用機構が明ら かにされると名称は変更される可能性がある。

$\mathrm{X}$ 器官は骨髄末梢の神経節細胞であり, サイナス腺と 連結している眼柄内の神経分泌細胞である(図 2 または 文献 4 中の図参照)。眼柄の分泌物は神経と内分泌系の 間の調節に関わる活性因子を含み, 脱皮抑制, 脱皮促進, 色素調節 ( 4 種), 卵巣形成調節, 血糖値調節 (数種), 塩 濃度調節因子などが知られている。神経分泌物は, $\mathrm{Ca}^{2+}$ と $\mathrm{K}^{+} に よ っ て$ 起こる分極が引き金になって活動電位を 生じ，エキソサイトーシスによって細胞外に出される。 $\mathrm{X}$ 器官の分泌物は季節的な組成変動があり, 夏期には脱 皮促進因子に富むことが示されている。この時期のY器 官は昆虫の前胸腺に似て神経ホルモンによる促進的支配 を受けていると推定される。

いままでの化学的知見によれば，MIH は 61 アミノ酸 残基からなるペプチド (図 4:8) ${ }^{111}$ または分子量が約 8,700 の二種のペプチドがある ${ }^{12)}$ とするペプチド説とイ ンドールアルキルアミン様物質13) とする小分子化合成物 説の二種があるが, 著者らが行った脱皮抑制物質の研究 結果 ${ }^{14)}$ を(3.) に紹介する。

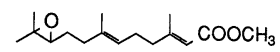

(7)

Asx (9), Thr (2), Ser (2), Glx (7), Pro (1), Gly (4), Ala (2), 1/2 Cys (4), Val (4), Met (1), Ile (3), Leu (5) Tyr (1), Phe (3), His (3), Trp (2), Lys (2), Arg (6) : (61)

(8)

Fig. 4 JH-III (7) and one of the proposed $\mathrm{MIH}(8)$.

\section{3. 脱皮抑制物質：エクジソン生合成阻害物質}

MIH の化学的研究が長年に渡って進展しなかった理 由には，a)甲殸類は自己分解し易いので化学的研究に 供する十分量の眼柄を入手し難い。b)生物の個体に多 様性があり（脱皮周期, 季節, 性別, 生育地などに基づく), 信頼できるアッセイ用生物の供給が阻まれている。c) ホルモンであることを証明することが困難である。など が主な問題点として考えられる。著者らは，これらの点 を克服して，カ二の眼柄から MIH 効果を示す化合物を 新しく工夫した生物検定法 (in vitro) に従って単離し，そ の化学構造を明らかにして，エクジソン生合成阻害物質 (ecdysone biosynthesis inhibitor : EBI) として働くこと を明確にするとともに，作業仮説に基づいてその分子機 構を推定した。また，アメリカザリガニ(Procambarus clarkii) を用いて in vivoでも脱皮抑制効果を示すことを 認めた。

3.1. 実験材料 予備実験の知見をもとにして実験用 の材料を以下のように調達した。秋から春にかけて冬期 を中心にアメリカ東部海岸で入手したブルークラブ (Callinectes sapidus)を, 生きた状態で氷で冷して固定し, 眼柄を切除する。切除した眼柄はドライアイスで凍結後, 凍結乾燥して MIH の材料として氷室に備蓄した。この 際のカ二は雌雄, 脱皮周期などを無視した無作為収集で ある。眼柄を切除した後にカ二を液体窒素によって急速 凍結してY器官の材料として保存した $\left(-80^{\circ} \mathrm{C}\right)$ 。この ように保存しても，エクジソンの生産能力は徐々に低下 するが，2〜3 月間は実験の材料として使用することが できる(約 $90 \%) 。$ 死後数時間を経過したカニのY器官 は，自己分解による劣化のため使用に堪えない。X 器官 と $\mathrm{Y}$ 器官の提供生物が異なっても(異種間のカ二, 淡水 性カ二など) 生物検定に差支えないことが判ったので, 以後は入手し易い生物のY 器官を使用した。

3.2. バイオアッセイ法( in vitro) 従来の報告 ${ }^{4,9)}$ は, RIA 法によって摘出 $\mathrm{Y}$ 器官の器官培養で生産される エクジステロイドを検出している。この方法の検出感度 は非常に高いが $(10 \mathrm{pg})$ ，骨格認識に基づく抗体を用い るのでエクジステロイドの個々の成分としては定量出来 ない欠点がある。また，器官培養法では検体の多様性に 対応する個体別の対照区が必要であるから，一個体にあ る 2 個のY器官を別々に分けて一群を対照区とし, 数個 体の平均値として扱っていた。著者らは器官培養の代わ りに数個体のY器官をホモジネートすることによって対 照区を減らすとともに，高速液体クロマトグラフィー (HPLC)によってエクジソンの定量を行った。これによっ 


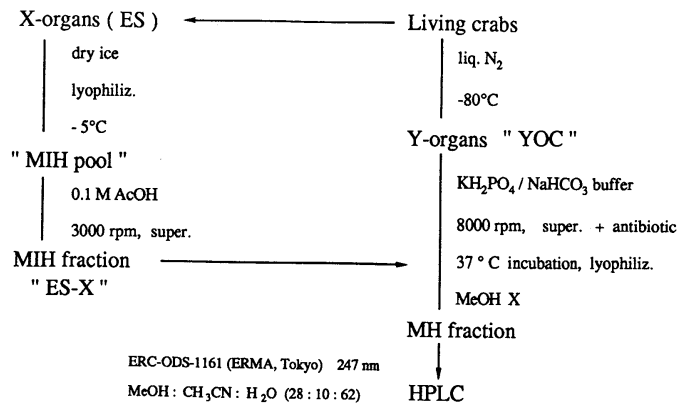

Fig. 5 Bioassay system for MIH/MH activity.

て, Y 器官が周辺組織および体液と混在しても, そこに 起因する 20 -ヒドロキシエクジソンを除外できるから, 分析值には影響がないし器官の摘出も容易になる。結果 的には $\mathrm{Y}$ 器官近傍由来の必要な醳素と基質を含むスープ をエクジソン生産に利用することになる。検出感度では RIA 法に劣るが, 抑制効果は化合物対応になり, 抑制効 果の検出法としては向上する。ちなみに, エクジソンの HPLCによる検出感度は $3 \mathrm{ng}$ であり, 最適季節の生物 の $1 \mathrm{Y}$ 器官当りの平均生産量以下である (後述)。バイオ アッセイシステムを図 5 に記す。

ギブスカッターを用いて甲殼の縁に沿って切込みを入 れ甲羅をはずし，Y 器官を $\mathrm{Y}$ 字筋と共に YOC ( $\mathrm{Y}$-organ complex) として摘出する。YOC は冷やした $0.17 \mathrm{M}$ のリ ン酸カリウム/炭酸水素ナトリウム緩衝液, $\mathrm{pH} 7.1$ で 表面を洗浄後, $100 \mu \mathrm{l} / \mathrm{YOC}$ の緩衝液の中でテフロン製 ホモジナイザーによって組織を破砕する(水冷下)。懸濁 液を遠沈管に移し $(1.2 \mathrm{ml} / \mathrm{YOC}) 5^{\circ} \mathrm{C}$ 以下にて遠心分離 する $(8,000 \mathrm{rpm}, 20 \mathrm{~min})$ 。沈殿を再度同量の緩衝液に 懸濁の後, 遠心分離し, 先の上澄液と一緒にして $1 \mathrm{ml}$ に付き $0.2 \mathrm{mg}$ のストレプトマイシンと $200 \mathrm{IU}$ のペニシ リンを加えて等量ずつに分け $(2.5 \mathrm{ml} / \mathrm{YOU}), 37^{\circ} \mathrm{C} て ゙$ 20 時間振盪培養する。培養が完了すると夫々の培養液 を凍結乾燥し，残渣をメタノールで抽出する。抽出液を セパック (SEP-Pak C 18)の短いカラムを通して $5 \mathrm{ml}$ の メ夕ノールで洗浄後溶媒を濃縮し, HPLC (ERCODS-1161，ERMA)によって産生したエクジソンを 247 $\mathrm{nm}$ の吸収を指標にして定量する(メタノール：アセ卜 ニトリル：水 $=28: 10: 62)$ 。定量用内部標品として, 14, 15-デヒドロ-20-ヒドロキシエクジソンを用い (20-ヒド ロキシエクジソンを $1 \%$ メタノール塩酸で処理して作 製), 検量線をもとにして定量する $( \pm 6 \%)$ 。

YOC の均一化培養法によるエクジソン産生量は冬期

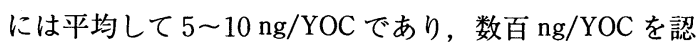
めた場合もある。カニの種類はイシガニ, ブルークラブ,
ガザミ (Charybdis japonica, Callinectes sapidus, Portunus trituberculalus) などである。エクジソンは HPLC 上の保 持時間およびHPLC から分取した画分をトリメチルシリ ル化後, GC-MS(ガスクロマトグラフィー連結質量分析) によって同定した。

\section{3. 脱皮抑制活性成分の単離 660 コ $(36 \mathrm{~g})$ の備蓄} した眼柄 $(\mathrm{ES})$ を 1 回について $200 \mathrm{ml}$ の $0.1 \mathrm{M}$ 酢酸で 6 回加熱抽出し, 15 分間遠心分離する $(3,000 \mathrm{rpm})$ 。上澄 を凍結乾燥し残渣の粉末を粗抽出物 (ES-X : 図 5) とし て抑制効果を調べた。即ち先のYOCホモジネートに $\mathrm{ES}-\mathrm{X}$ を加えて $(\mathrm{ES} / \mathrm{YOC}=1: 1) 37^{\circ} \mathrm{C} て ゙ 20$ 時間培養し, ES-X が添加されていない対照区に比べてエクジソン生 産量がどれだけ隇少したかを，HPLCの面積より算出す る。抑制効果は異種間でも認められ，種特異的ではなく かなり広範な甲款類に共通であることが明らかになっ た。

上記のアッセイ法に従って図 6 のように分画を行っ た。660コの眼柄粗抽出物, ES-X (16 g)をセファデック ス G-25 で分子フルイにかけ， $280 \mathrm{~nm}$ の吸収を指標にし て7 分画しそれぞれ凍結乾燥した。活性を認めた画分 V を更に G-10に導通 (0.1 M 酷酸) したのち, 陽イオン交 換樹脂 $(\mathrm{MCI}$ ゲル, CK $10 \mathrm{~V}$ 三菱)を用いて, 均一グラヂ エント $(0.8 \mathrm{M}$ 酢酸 $/ 0.4$ ～ $\mathrm{M}$ アンモニア水) 溶出に よって精製した。この成分は電気泳動の挙動(セルロー ズ， $0.4 \mathrm{M}$ 酢酸 $/ 0.12 \mathrm{M}$ ギ酸 $1 ： 1 ， \mathrm{pH} 2.5)$ から, Soyez ら ${ }^{13)}$ によって報告された化合物と同一であると推 定された。単離成分 $(700 \mu \mathrm{g})$ を常法に従って, 核磁気共 鳴 (NMR: $\left.{ }^{1} \mathrm{H},{ }^{13} \mathrm{C}\right)$, 紫外線吸収 (UV), 円二色性 (CD) などの各種スペクトル,アミノ酸分析, 質量分析 (EI-MS) などによって，3-ヒドロキシ-L-キヌレニン [図 7：9] であると同定した。 $\mathrm{C}_{10} \mathrm{H}_{12} \mathrm{~N}_{2} \mathrm{O}_{4}, m / z=224,4-\mathrm{H} 6.85 d$, $5-\mathrm{H} 6.42 d d, \quad 6-\mathrm{H} 7.21 d, \quad 3{ }^{\prime}-\mathrm{H} 3.25 d d, 3.53 d d$, 2 '- $3.63 d d, \mathrm{NH}_{2} 6.71 s$ (DMSO)。UV (0.005 M 塩酸中) $224 \mathrm{~nm}(\varepsilon 18,400), 266 \mathrm{~nm}(\varepsilon 7,600), 370 \mathrm{~nm}(\varepsilon 4,000)$; $\mathrm{CD}(0.005 \mathrm{M}$ 塩酸中 $) 231 \mathrm{~nm}(\Delta \varepsilon+1.0), 273 \mathrm{~nm}(\Delta \varepsilon+$ $0.5), 370(\Delta \varepsilon-0.2)$ 。

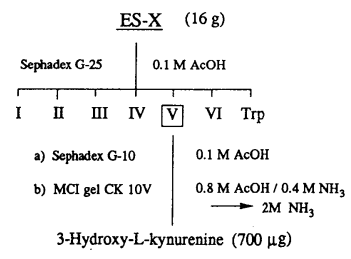

Fig. 6 Isolation of "MIH" from eyestalks (Callinectes sapidus). 


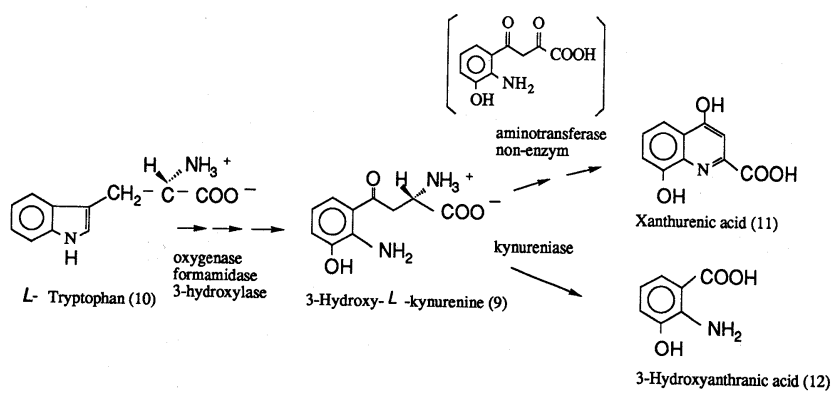

Fig. 7 Metabolic pathway of tryptohan to MIH active substances.

標準試料品*1 の $\mathrm{L}$-体は上記に得た天然品と同程度の 活性を示したが, 粗抽出物 (ES-X)の活性には及ばなかっ た。しか, 合成 DL 体*2では活性が発現しないことから, 培養(アッセイ)の途上で醳素的に変換した代謝物が抑制 効果を示す本体であると予測して代謝物の抑制効果を調 べた。

3.4. キサンツレン酸と抑制効果３-ヒドロキシキヌ レニン $(3-\mathrm{OH}-\mathrm{K})(9)$ はトリプトファン $(10)$ の中間代謝 物であり, 更にキサンツレン酸(11) または 3 -ヒドロキ シアンスラニル酸(12)に代謝される(図 7)。代謝物を検 索した結果, キサンッレン酸 $(\mathrm{XA})$ に強い抑制活性があ ることを認めたので, 抽出法を変えることによって眼柄 から XAを検出した。即ち, ES-X を酢酸アンモニア水 $(0.17 \mathrm{M}, 250 \mu \mathrm{l} / \mathrm{ES}, \mathrm{pH} 5)$ で抽出し, 遠心分離 $(3,000$ rpm, $15 \mathrm{~min}$ ) し, 上澄をゲル滤過 (Asahipak GS 320) し 酢酸アンモニア水 $(0.17 \mathrm{M})$ で $3-\mathrm{OH}-\mathrm{K}$ を溶出後, $20 \%$ のアセトニトリルを添加した酢酸アンモニア水 $(0.17$ M)によってXAを溶出した。標品との添加クロマト法 (HPLC) によってXAであることを同定確認した。 $\mathrm{C}_{10} \mathrm{H}_{7} \mathrm{NO}_{4}, \quad m / z=205,3-\mathrm{H} 6.92 s, 5-\mathrm{H} 7.28 d d, 6-\mathrm{H}$ $7.35 t, 7-\mathrm{H} 6.95 d d\left(\mathrm{NH}_{4} \mathrm{OD}\right)$ 。

眼柄抽出物 $(\mathrm{ES}-\mathrm{X})$ の $\mathrm{ED}_{50}$ (エクジソン生産量を $50 \%$ 抑制する試料量) は ES-X の約 $1 \mathrm{mg}$ であり, $1 \mathrm{ES}$ から $25 \mathrm{mg}$ の ES-X が得られたので $1 \mathrm{mg}$ の ES-Xは $0.04 \mathrm{ES}$ に相当することがわかった(図 8)。ES-X の $1 \mathrm{mg}$ 中の $3-\mathrm{OH}-\mathrm{K}$ 抢よびXA の含有量はそれぞれ $136 \mathrm{ng}$ と $78 \mathrm{ng}$ であり (HPLC $240 \mathrm{~nm}$ 検出法), もし $3-\mathrm{OH}-\mathrm{K}$ から XA への変換が培養中に $100 \%$ 進行したと仮定しても, 分子 量を考慮に入れると ES-X の $1 \mathrm{mg}$ は $203 \mathrm{ng} の \mathrm{XA}$ に相 当する。XA の $\mathrm{ED}_{50}$ は約 $250 \mathrm{ng}$ であり, 全ての活性を XA だけで説明することは出来ない。従って, 抑制効果

*1）梅鉢幸重教授(金沢大学)より供与。

*2）妹尾四郎博士 (当財団副理事長)より供与。

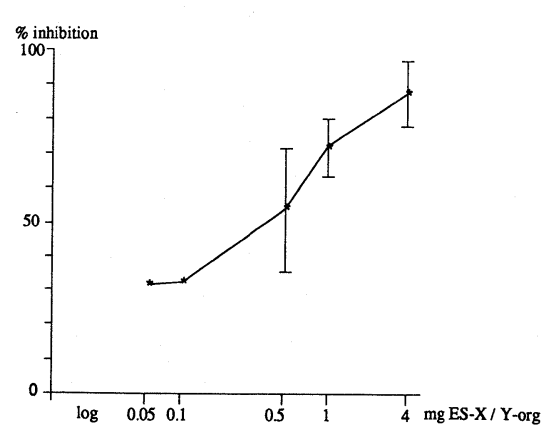

Fig. 8 Dose response of "MIH" inhibitory effect (ES-X) .

は単一成分よりはむしろ多数因子 ${ }^{11,12)}$ が絡んだ複雑な支 配下にあると推定される。

3.5. X- 器官と抑制物質, $3-\mathrm{OH}-\mathrm{K} \rightarrow \mathrm{XA}$ の変換 ES-X から MIH 活性物質として 3-OH-K と XA を同定し たが, さらにX器官一サイナス腺での存在を確認するた め, 眼柄を生体 (8 個体) から切除し, 生理食塩水中で注 意深く解剖して目的器官を摘出し, 酢酸アンモニア水で 抽出, 遠心分離し, 上述と同様に分析した。この場合に は (季節, 個体によって変動), 1 器官あたり $28 \mathrm{ng} の$ 3-OH-K と $128 \mathrm{ng}$ の XA が検出され, それぞれ ES-X の 〜 \%および〜 7\%に相当することが判った。以上の結 果から, キサンツレン酸は眼柄のみならず $\mathrm{X}$ 器官の内生 的物質でもあることが確認できた。

一方, カ二の体液をリン酸一炭酸水素ナトリウム緩衝 液で抽出し, 硫酸アンモニウムで処理後沈殿物を遠心分 離, 上澄を透析して, 透析されない蛋白質画分をセファ デックス G-200に導通して粗酵素(アミノトランスフェ

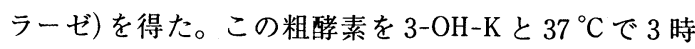
間培養後, 透析, 透析液を HPLC (Asachi Pak GS 320)に よって定量し，61％がXAに変換されたことを認めた。 従って3-OH-K がX器官から分泌されてY器官に輸送 
される時に体液中または YOC 付近でXAに変換されて いることも有り得る。3-OH-Kを YOC ホモジネートに 添加培養する時にはその $90 \%$ が失われたが, XA の増 加としては認められなかった。この結果は, XA が YOC で異化作用をうけると同時にエクジソン合成の際に消費 されている可能性を示唆するものである。

実際，YOC ホモジネートを用いたエクジソン合成阻 害試験で, $37^{\circ} \mathrm{C}, 20$ 時間の培養では ES-X, 3-OH-K, $\mathrm{XA}$ ，の三者は同程度の阻害効果を示したが，培養時間 が短い場合 (1 時間以内)には，その間に合成されるエク ジソン前駆体(デオキシエクジソンと推定)の生産を阻害 するのは ES-X と XA の両者であり, 3-OH-K は同程度 の阻害効果を示すのに長時間を必要とした。 $\mathrm{ED}_{50}$ に基 づく定量的な阻害効果の相互関係は現在実験中である。

\section{4. 作用機構 ${ }^{15)}$}

エクジソンの生合成に酸素添加酵素が介入するという 作業仮説のもとに，モデル酵素としてチトクロームCを 選んで, XAの阻害作用機構を検討した。XA の存在下 ではチトクロームCの電子スピン共鳴スペクトル (ESR) は典型的な結合型 $\mathrm{Fe}(\mathrm{III})-\mathrm{O}$ を示した $(\mathrm{g}=2.30,2.12$, $1.88,77 \mathrm{~K})$ 。この結合は NADPH-チトクロームC 還元 酵素で還元されず不可逆的であった。また可視吸収スペ クトルの $\gamma$-ピーク (Soret peak)でも長波長シフト $\left(\lambda_{\max }\right.$ $410 \rightarrow 415 \mathrm{~nm})$ が認められ, チトクロームC が XA と結合型 に変わることが示された。XAに低濃度のチトクローム C を徐々に添加する時, 動的 NMR は 3-H および $6-\mathrm{H}$ が大きく低磁場シフトする。この結果から，4-OH が $\mathrm{Fe}-\mathrm{O}$ 結合に関与していることが推定され, XA の互変 異性体の一つがチトクローム Cの鉄ポルフィリン上の第 5 配位子として不可逆的に結合して, 電子伝達系の電子 の流れを止めるためにエクジソン前駆体(基質)への酸素 添加が起こらないと考えられる(図 9)。同様の結合は 3-OH-K とチトクローム C との間では認められなかっ た。エクジソン生合成にチトクローム $\mathrm{P}_{450}$ が関与して いるかどうかは今後の研究を待たなければならないが,

Fig. 9 Interaction of $\mathrm{XA}$ and Cytochrome $\mathrm{C}$; a possible mode of ecdysone biosynthesis inhibition.
上記と類似の酵素阻害剤としての作用機構が脱皮抑制の 初発反応として示唆される。

一方，エクジソンの 20-位に水酸基を導入する活性を 持つカニの体液に, XA を添加培養しても20-位の水酸 化は阻害されないし, 昆虫 ${ }^{16)}$ を使った同様の反応でも 20-位の水酸化は阻害されなかった。20-位の水酸化に $\mathrm{P}_{450}$ が関係していることはすでに知られているので, エ クジステロイド生合成途上の水酸化反応では認識部位が 異なる酵素を段階的に介しているものと推定される。力 二の脱皮の D 期 (上述) 以降の時期には, “MIH”効果が 期待出来ない所以でもあろうか?

\section{5. キサンツレン酸は MIH か ? ${ }^{17)}$}

ホルモンの定義は「特定の細胞 (内分泌細胞または一 部の神経細胞)によって, 生体内外の情報に応じて生産・ 分泌され, 体液を介してその情報をほかの細胞 (標的細 胞)へ伝達する物質」とされている。XA は神経節細胞 であるX器官で産生されると同時にX器官で産生された 3-OH-K の体液中またはYOCでの変換産物である。同 じ個体を用いて脱皮関連物質 (3-OH-K, XA, エクジソン) をそれぞれ定量分析 (1 回の分析は 6 個体の平均值)して 周年変動を調べた。YOCについては，10月〜3 月頃の イシガニではXA が極大值 ( 300 ng/YOC) を示すのは 11 月頃で, エクジソンが極大值 ( 30ng/YOC)を示すの は 2 月頃であり両者の間に明確な山と谷の位相差が認め られた。4月〜10月の期間には $3-\mathrm{OH}-\mathrm{K}$ およびXA の変 動は極めて小さい振幅であり, 累積量も少ない。イシガ ニはこの期間中に頻繁に脱皮を行うので脱皮周期による 多様性のために平均値としては小さい変動として現れた ものと思われる。一方, 眼柄中の XA の変動は一年を通 して小さな振幅であるが，3-OH-Kの振幅には大きな山 が 2 回あった。そのうち 1 回 (3 月) はYOC中の 3-OH-K の振幅と同調しているが, 他の 1 回 (9 10月) は YOC 中の XA の増加前兆期として解釈できる。

同じカニの体液 $1 \mathrm{ml}$ 中に遊離型として検出されるXA および3-OH-Kの量は一年を通して常に微量であり, この量的な比較からはXA はYOCにおいて蓄積されて いるものと推定される(結合型の存在については不明で ある)。分泌の消長的な動態はホルモン様であり, しか も XA は YOC と親和性に富み, 機能の発現はYOCでの み認められる。しかしながら，XA が上述のような酵素 阻害の機構で活性を発現するのであれば，終局的に脱皮 を抑制したとしてもエクジソン生合成阻害物質 (EBI： Ecdysone Biosynthesis Inhibitor) として位置付けされる べきであり，3-OH-K はその前駆体である。従って MIH 
に相当する物質が存在するか否かは将来の研究を待たな ければならない。

\section{6. in vivo 脱皮抑制効果 ${ }^{17)}$}

in vivo の脱皮抑制効果は，20-ヒドロキシエクジソン を注射した場合に脱皮周期上のある限定された期間 (C 後期)でのみ有効であることが報告さている4)。従って, 脱皮を抑制する効果も脱皮の周期と密接に関係するであ ろうことが予測される。多数の歩脚を自己切断させるか, 眼柄を切除した場合に脱皮周期が促進される知見 ${ }^{4)}$ を基 にして，実験生物としてアメリカザリガニ (Procambarus clarkii）を選び，in vivo の脱皮抑制効果を調べた。抑制 物質として 3-OH-K を使った理由は XA の生理食塩水に 対する溶解度が極度に小さいためである。体長がほほ同 ビアメリカザリガニ $($ 約 $7 \mathrm{~cm})$ を 10 個体づつの $\mathrm{A}, \mathrm{B}$ 群 に分け，全ての生物の鉗脚を基節から自己切断 (物理的 刺戟による)させ，同時に眼柄を切除し，それを0日と した (図 10)。A 群を対象区としてB 群の生物に毎日 30 $\mathrm{ng} / 0.1 \mathrm{ml}$ (生理食塩水)の $3-\mathrm{OH}-\mathrm{K}$ を注射した。A 群の 生物は手術後 5 日までに 3 個体が死亡し，6８日の間 に 7 個体が脱皮したが完全に脱皮に成功して生き永らえ たのは 3 個体であった。一方，B 群では手術後 2 日目に 1 個体が死亡し, $7 \sim 11$ 日の間に 9 個体が脱皮し 3 個体 が生き残った。2 回目の脱皮はA 群では 15〜17 日目に, B 群では 19〜21 日目に観察された。この結果によると 3-OH-K の注射によって脱皮期間は 1 ～3 日延長した。 脱皮の途中で死亡した個体の胃石は $\mathrm{A}$ 群の 4 個体の平均 值が $169 \pm 65 \mathrm{mg}$ で, B 群の 6 個体の平均值が $227 \pm 57$

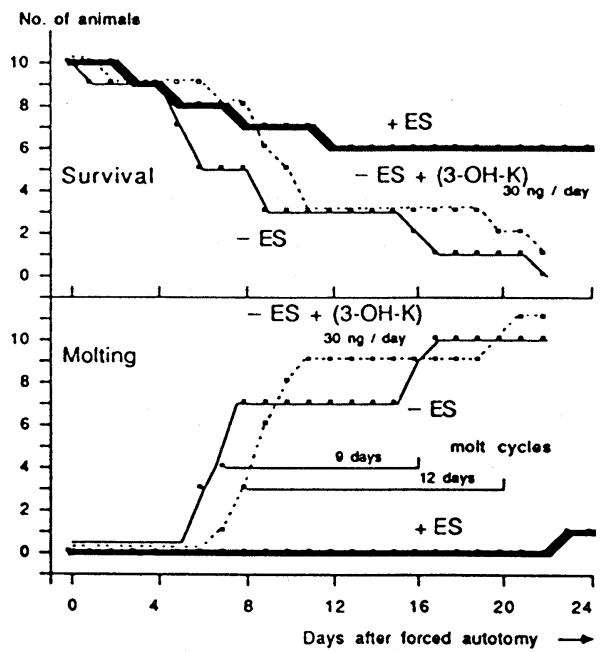

Fig. 10 Effect of 3-OH-K injection to crayfish, Procambarus clarkii. $\mathrm{mg}$ であり, B 群の脱皮抑制効果は胃石の大きさからも 判定された。鈤脚を自己切断させたが眼柄を除去しない 生物では鉗脚の自己切断後 22 日までに脱皮した個体は なく，その間に死亡した 4 個体にも胃石の形成は見られ なかった。したがって，眼柄切除によって特に死亡数が 増加することはないが脱皮時に死亡する数は多い。これ が眼柄の切除によって生じた生理的な障害に基づくかど うかは不明である。現象的には，眼柄切除によって促進 された脱皮は 3-OH-K の注射で抑制されたことになる。 なお，注射の量はアメリカザリガニ 11 個体の X器官か ら検出されたXA の平均值 $40 \mathrm{ng}$ 即ち $80 \mathrm{ng} / 1$ 個体の約 $40 \%$ が有効と仮定して $30 \mathrm{ng} /$ 日を採用したものであり 必ずしも最適量ではない。毎日注射したのは, 3-OH-K が比較的早く代謝されるという推定に基づいている。0 日に先立った抑制剤の導入なども将来考慮すべき点であ り，効果を示す最適条件も検討されていないので脱皮抑 制期間がどのくらいであれば効果があると言えるのか, 抑制効果が眼柄切除効果のすべてを回復可能なのかどう かは将来の研究を待たねばならない。現段階では脱皮を 現象的でなく，体液中のエクジソンまたは 20 -ヒドロキ シエクジソン量の変動として把握することで，抑制効果 に定量性を持たせるべく努力中である。

\section{7. 結論と問題点}

20-ヒドロキシエクジソンと MIH が甲款類の脱皮現象 に拮抗する因子であるという概念はすでに長く定着した が, 脱皮現象は一連の形態的, 生理的, 生化学的变化を 伴うので多数の因子が介在するであろうことは容易に推 定される。従って, 一つの生理活性物質が一つの現象を 説明し得るとは限らないので, 介在する全ての物質の分 子構造が明らかになり, 作用機構が解明されるまで結論 は避けるべきだろう。

エクジステロイドは多数の甲殼類から単離され同定さ れた ; 分泌量は脱皮周期の時期によって変動する;外部か ら導入されたエクジステロイドは脱皮現象を促進する； $\mathrm{Y}$ 器官はエクジソンの主たる生産器官である;摘出器官 を培養するとエクジソンが生産され，Y器官を摘出した

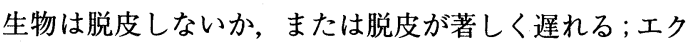
ジステロイドの生産器官がY器官以外にもありうる; 同 種の生物でも環境の違いによってエクジステロイドの分 泌量は大きく変化する; エクジソンは中腸腺および睪丸 などで 20 -位の水酸化をうけて機能を発現する;

果たしてエクジステロイドは脱皮以外の事象にどれだ け関わっているのか，脱皮に終局があるのか，もし終息 するならY器官が退化するのか，または分泌だけが停ま 


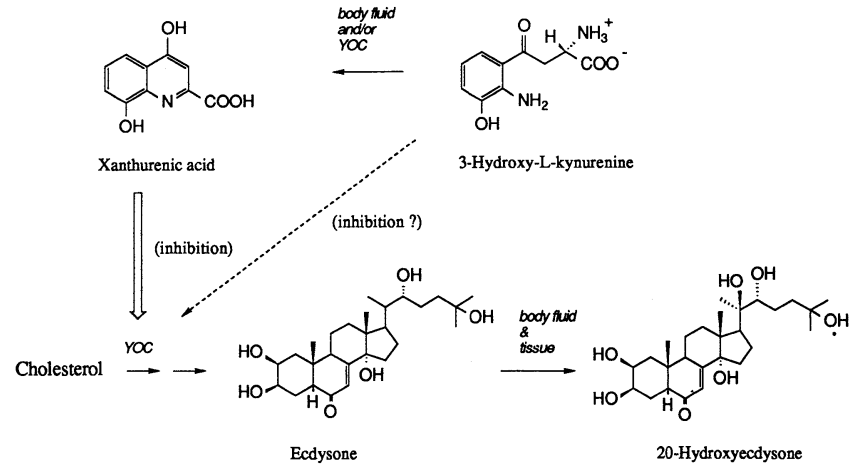

Fig. 11 Flow chart of chemicals involved in ecdysis phenomena of crustaceans.

るのか, 何が分泌を支配しているのだろうか？

一方, 眼柄を切除すると体液中の全カルシウム濃度が 上昇し，眼柄抽出物を注射すると低下する;この因子と MIH の関係は明らかでないし, 肝臓での脂質合成も眼 柄の内生物質で抑制されているが，MIH との関係では 判っていない; X 器官で生産される脱皮抑制物質は熱に 安定で種間に共通の物質であり, MIH は摘出 Y 器官が 生産するエクジソンの合成を抑制する：5-ヒドロキシト リプタミンまたは5-ヒドロキシトリプトファンは, $\mathrm{MIH}$ 活性物質の分泌を増進させることが，摘出した眼 柄の神経節を用いて示されている ${ }^{18)}$; アミノ酸残基 61 から成るぺプチド (8)はN 末端がブロックされており $250 \mathrm{pM} / 1$ 以上 (最低分子量：7,200) で in vitro の活性が

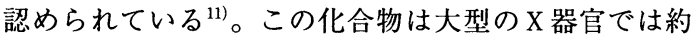
$30 \mathrm{ng}$ 小型の器官では $7 \mathrm{ng}$ が検出された; 高血糖ホルモ ン (HGH : Hyperglycemic hormone) が多少ともエクジソ ン合成阻害に関係している可能性も示唆されている クルマエビ (Homarus americanus) の in vivo 試験によれ ば, 活性物質は分子量約 8,700 のペプチドであり脱皮抑 制期間の延長は対照区に比べて 1 2 日である ${ }^{12)}$ 。

著者らは，脱皮抑制現象を示す化合物としてキサンツ レン酸を明らかにし，エクジソン生合成阻害物質 (EBI) として定義した。その作用機構として, 介在する酵素に 不可逆的に結合して, 電子伝達機構を妨げるためにエク ジソンの生合成を抑制すると推定した。in vivo 効果を 調べるために前駆体 3-OH-K を注射して対照区に比べ て脱皮周期が延びる $(1 \sim 3$ 日)ことを認めた。図 11 には 現在までの知見をもとにして, 脱皮に関係する化学物質 を構造式で示す。

本当に特定の受容体をもつホルモン MIH は存在する のだろうか？ 神経伝達物質によって分泌が増進される 化合物は何なのか?

\section{文献}

1) D.M. Skinner. Biol. Bull. (Woods Hole, Mass.) 123, $635(1962)$

2) C. Zeleny, J. Exp. Zool., 2, 1 (1905)

3) F.A. Brown, jr., O. Cunningham, Biol. Bull., 77, 104 (1939)

4) D.M. Skinner, "Molting and Regeneration", pp.43-146 ; L.H. Kleinholz, "Biochemistry of Crustacean Hormones", pp.464-522, In The Biology of Crustacea, (D.E. Bliss, L.H. Mantel, eds.) Vol.9 (1985) . Academic Press, New York

5) S. Natori, Devel. Biol., 50, 395 (1976)

6) J.H. Nishiura, J.W. Fristrom, Proc. N.A.S., USA, 72, 2984 (1975)

7) E.G. Fragoulis, C.E. Sekeris, Eur. J. Biochem., 51, 305 (1975)

8) E.S. Chang, B.A. Sage, J.D. O’Connor, Gen. Comp. Endocr., 30, 21 (1976)

9) L.H. Kleinholz, R. Keller, "Endocrine Regulation in Crustacea" in Hormones and Evolution, Vol.1, pp.160-213 (1979) Academic Press, NY.

10) H. Laufer, D. Borst, F.C. Baker, C. Carrasco, M. Sinkus, C.C. Reuter, L.W. Tsai, D.A. Schooley, Science, 235, 202 (1987)

11) S.G. Webster, R. Keller, J. Comp. Physiol. B., 156, 617 (1986)

12) E.S. Chang, M.J. Bruce, R.W. Newcomb, Gen. Comp. Endocr., 65, 56 (1987)

13) D. Soyez, L.H. Kleinholz, ibid ., 31, 233 (1977)

14) Y. Naya, K. Kishida, M. Sugiyama, M. Murata, W. Miki, M. Ohnishi, K. Nakanishi, Experientia, 44, 50 (1988)

15）未発表デー夕

16) S.L. Smith (Bowling Green State University), 私 信。

17）未発表デー夕

18) M.P. Mattson, E. Spaziani, Biol. Bull., 169, 246 (1985) 